\title{
Death and the Plowman or, The Bohemian Plowman
}

\section{A Disputatious and Consolatory \\ Dialogue about Death from the Year 1400}

Johannes von Saaz

translated by

Ernest N. Kirrmann 
Death and the Plowman or, The Bohemian Plowman 
From 1949 to 2004, UNC Press and the UNC Department of Germanic \& Slavic Languages and Literatures published the UNC Studies in the Germanic Languages and Literatures series. Monographs, anthologies, and critical editions in the series covered an array of topics including medieval and modern literature, theater, linguistics, philology, onomastics, and the history of ideas. Through the generous support of the National Endowment for the Humanities and the Andrew W. Mellon Foundation, books in the series have been reissued in new paperback and open access digital editions. For a complete list of books visit www.uncpress.org. 



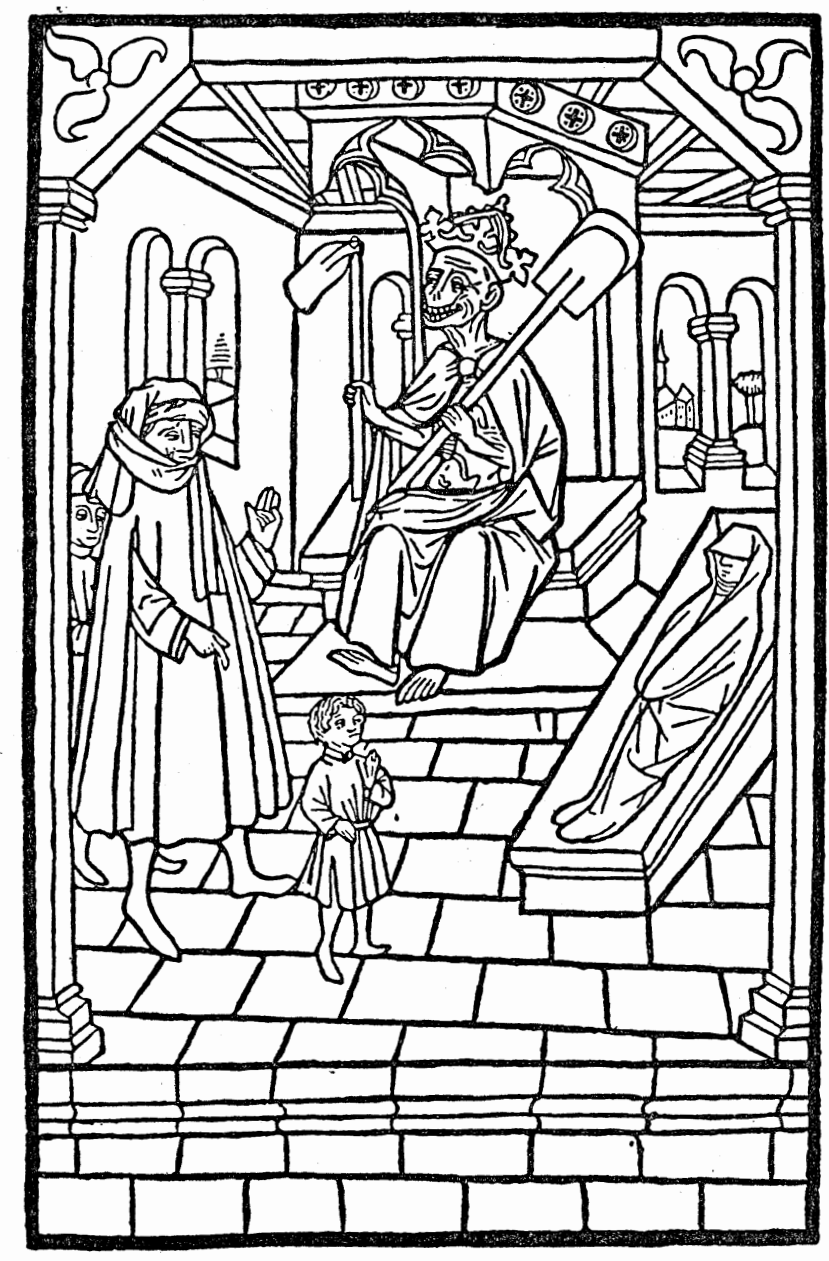




\section{Death and the Plowman or, The Bohemian Plowman}

A Disputatious and Consolatory Dialogue about

Death from the Year 1400

Translated from the Modern German Version of Alois Brent

BY JOHANNES VON SAAZ

TRANSLATED BY ERNEST N. KIRRMANN

UNC Studies in the Germanic Languages and Literatures

Number 22 
Copyright (C) 1958

This work is licensed under a Creative Commons CC BY-NC-ND license. To view a copy of the license, visit http:/ / creativecommons. org/licenses.

Suggested citation: Saaz, Johannes von. Death and the Plowman or, The Bohemian Plowman: A Disputatious and Consolatory Dialogue about Death from the Year 140o. Translated by Ernest Kirrmann. Chapel Hill: University of North Carolina Press, 1958. DoI: https://doi. org/10.5149/9781469657646_vonSaaz

Library of Congress Cataloging-in-Publication Data Names: Kirrmann, Ernest N.

Title: Death and the Plowman or, The Bohemian Plowman : A disputatious and consolatory dialogue about death from the year 1400 / by Ernest N. Kirrmann.

Other titles: University of North Carolina Studies in the Germanic Languages and Literatures ; no. 22.

Description: Chapel Hill : University of North Carolina Press, [1958] Series: University of North Carolina Studies in the Germanic Languages and Literatures.

Identifiers: LCCN 58063297 | ISBN 978-0-8078-8022-7 (pbk: alk. paper) | ISBN 978-1-4696-5764-6 (ebook)

Classification: LCC PD25.N6 NO. 22 
I N M E M O R I A M

Ernst Dehnhardt

Buchenwald 194?

Friend and Companion of my youth

Whose "deviation" was that he had become blind 
The woodcuts accompanying this text are from the earliest known printed copy of the Ackermann aus Böhmen (Bamberger Pfisterdruck, ca. 1462). They are reproduced here' with the permission of the Insel-Verlag in whose Inselbücherei Alois Bernt's modern German version first appeared in 1916. 


\section{TRANSLATOR'S PREFACE.}

Not one of the sixteen known manuscripts of the Ackermann aus Böhmen is a first copy of the lost original. They are all one or more generations younger and date from the middle decades of the fifteenth century on.

Short of discovering an earlier, first copy-or the original $A a B$ itself! - scholarly research has to content itself with establishing the genealogy of the surviving MSS. The internal evidence of errors made in copying, and errors perpetuated by copying, points to one or more, somewhat inaccurate, lost first copies. The work of reconstructing such a hypothetical archetype is not yet complete; that of reconstructing a hypothetical original well-nigh impossible.

Nearest in time to the original stands Tkadlec, a somewhat free, Czech translation, the original of which, done not before 1408 , is also lost. It has the virtue of being contemporary with the $A a B$ 's author and serves as a control of copyist errors. The MS agreeing most closely with $T k$ is MS. E (ca. 1490) ; however, it is fragmentary and contains barely the first third of the text.

To Bernt belongs the distinction of having done the spade work of collating the MSS and the printed copies of the $A a B$, and of having given the German reading public a poignant and readable modernization of this classic. The popularity of the Bernt version is vouchsafed by the fact that some 100,000 copies of it have been printed since its first appearance in 1916.

I make therefore no apologies for having based my translation on Bernt. The basic work was done before more recent modernizations and dramatizations appeared in Europe and, in any case, before I was aware of their existence. A few instances where I have followed newer interpreters are noted in the Appendix. They might well serve as a sampling of the many problems confronting the investigators in their attempt to reconcile the discrepancies in the surviving manuscript copies.

Since the present work is intended for the perceptive English speaking reader and the student of comparative literature in 
translation, the short list of critical text editions and commentaries may suffice.

1. Keith Spalding, ed., Johann von Tepl, Der Ackermann aus Böhmen, (Oxford, 1950; Blackwell's German Texts).

2. M. O'C. Walshe, ed., Johann von Tepl, Der Ackermann aus Böhmen, ed. with introduction, notes and glossary, (London, 1951).

3. L. L. Hammerich, \& G. Jungbluth, ed., Der Ackermann aus Böhmen, Part I: Bibliography, Philological Introduction, Critical Text with Apparatus, Glossary, (Copenhagen, 1951).

4. W. Krogmann, ed., Johannes von Tepl, Der ackerman. Deutsche Klassiker des Mittelalters, N.F. 1, (Wiesbaden, 1954).

For a synopsis of the views of the two most divergent schools of interpretation of the $A a B$ (Hübner-Schafferus: rhetoricaldialectic, stylistic exercise, thoroughly steeped in medieval tradition vs. Burdach-Bernt: in form and content, first great Renaissance document of German literature) and a reconciliation of these views, consult:

5. E. A. Philippson, "Der Ackermann aus Böhmen. A Summary of Recent Research and an Appreciation," Modern Language Quarterly, II, 263 ff.

6. Renée Brand, Zur Interpretation des Ackermann aus Böhmen. Basler Studien zur deutschen Sprache und Literatur, ed. W. Muschg \& F. Ranke, Heft 1, (Basel, 1944).

7. Arno Schirokauer, "Die Editionsgeschichte des Ackermann aus Böhmen: Ein Literaturbericht," Modern Philology, LII, 145-158.

8. Isaac Bacon, "A Survey of the Changes in the Interpretation of 'Ackermann aus Böhmen'," Studies in Philology, LIII, 101. 113.

Traduttore, traditore is an aphorism which applies to this translation as it must to all translation. The translator can only pray that he has understood his text and rendered it to the best of his ability. 


\section{PREFACE}

to the German Edition

The Bohemian Plowman (Der Ackermann aus Böhmen), which is here presented to a larger circle in a transcription into modern German (and translated herewith into English), is the most profound prose writing of German Humanism. It is the first bloom and at the same time the finest fruit of the spiritual awakening of Man out of the narrow confines of the Middle Ages. The product of the striving scientific spirit of the incipient Renaissance in a period when, on German-speaking soil, only Bohemia had as yet embraced the new movement, it represents a linguistically powerful work, of unsurpassed artistry in construction and poetic form, a monument of German literature such as neither poetry nor prose was again to produce until Luther's day.

Proof of the importance and popularity of this disputatious dialogue for well over 150 years after its appearance, can be derived from the fact that sixteen manuscripts and seventeen different imprints from the fifteenth and sixteenth centuries have survived down to the present. Only a few works of the German Humanistic Age have enjoyed such popularity and distinction during that period. Nor had the Bohemian Plowman been neglected during the Classical Period by Lessing (17291781), the great connoisseur and protagonist of German Literature. Gottschedt thought so highly of it that he copied it in his own hand. Gervinus, in his History of German Literature called it "the most perfect prose writing which we possess in our older literature" and Wackernagel echoed his sentiments. Konrad Burdach, however, with his penetrating and thorough study of the incipient Renaissance, is the first one to weave the laurel wreath which the author of this masterpiece so justly deserves.

In the thirteenth century, St. Francis of Assisi preached a renewal of the Christian man; long before him, in St. Augustine's writings, the return of mankind to the pristine state of Paradise had been presented as a Church ideal. Dante, in his 
mind's eye, saw a re-birth of the world; Petrarch longed for a Golden Age and the re-establishment of the grandeur that was Rome's; Rienzo sought to bring about the latter by political means. All these movements were paralleled by reform movements within the Church itself. In the fourteenth century, however, the movement found its adherents outside the Church in the Italian aristocracy of birth and intellect and fixed its sights toward civilization, art and science and upon the ultimate ends of Man himself. It was natural, therefore, that through it the formative arts and the writings of Antiquity became infused with new life in Italy. Simultaneously, efforts were made to improve the vernacular through linguistic and stylistic embellishment, through rhetorical force and fullness. It was an intellectual movement: Modern Man made his first appearance on the world stage.

The relationship of the intelligentsia and the Court circles in Bohemia with several of the leaders of this Italian Renaissance of the fourteenth century was a close one and of long duration. With zeal and understanding, the well-educated literary circle around Charles IV responded to the stimuli that came from it, particularly in the literary and linguistic-stylistic realm, and with them the famed documentary style of the Prague Chancellery was developed and shaped. From this circle, the author of the Bohemian Plowman must have sprung. Johannes von Saaz, imbued with the old learning of his time and feeling the breath of the new one, was a man of considerable repute in Saaz where he held public office. A strange obscurity lies over his personality to which he himself contributed by concealing his name and profession behind the acrostic riddles of his book. From his work we only learn that his name was Johannes, that he practiced his calling with the pen, and that his wife died in childbirth on the second of August 1400.

My researches have shed some light on the external circumstances of the author. His real name was Johannes von Schüttwa (Sytbor) from West Bohemia, though, at times he also called himself "von Tepl." A cunning priest, by the name of Cubico, 
cheated him out of the patrimony left him by his father Heuslin von Schüttwa. In all likelihood he was born about the year 1360 and, without a doubt, studied at the University of Prague where he received his Magister and, almost certainly, spent a few years in the Royal Chancellery. From 1383 on, we encounter him as Town Clerk and School Rector of the City of Saaz while being, at the same time, invested with the office of Public Notary of the Diocese of Prague. Documents dating back to the thirteenth century show Saaz to be then a city governed under German law and having a German citizenry which preserved its German atmosphere down to the Hussite War of 1420, when the rule of the city fell into the hands of the lower burgher class which had accepted the Taborite teachings. From then on the city was for a long time the center of the extreme Hussite faction and possessed a second "Johannes the German." This second John had been the original advocate of the Taborite Doctrine, or, as one of the Hussite leaders characterized him, "the leading master of heresy."

Our schoolmaster and city scribe, the first Johannes, can be traced in the Archives of Saaz through twenty-eight years as an active, respected and, apparently, well-to-do man. From 1388 on he owns a house with a tower near the city walls; in 1408 his daughter Cristinella enters a second marriage. In 1404, at the behest and upon the commission of two citizens of Eger, Johannes produced a magnificent Latin Officiale of St. Jerome, complete with illuminated pictorial initial, which is today in the Nationai Museum of Prague. From his activity as city scribe a number of style books (formularies) and copy books of documents and letters have been preserved which give an insight into his official duties and, occasionally, glimpses into his private affairs. His prolific activity at Saaz comes to an end on April 9, 1411 when the city council gives him a splendid testimonial shortly before he heeds the call to Prague to become Notary of the New City there. His activity as First Secretary of the City Council of Prague is of short duration, though. On the 5th of April 1411 he purchases a house and lot from a nun of the Con- 
vent of St. Francis; by March of 1413 he is seriously ill and has to provide a substitute for his office. Death comes to Johannes probably in 1414, for on the 24th of April 1415, his widow Clara sells the house then belonging to her and her minor son George. The author of the Plowman, thus, did enter a second marriage after all. These facts, in short, are all that is known of the life of this important man.

The time around 1400 was a stormy one for Bohemia. (In 1347, Charles IV, of Luxemburg, had become Holy Roman Emperor and founded the New City of Prague, where-paradoxically, on non-German soil-he established the first German university a year later, in 1348. His successor, as King of Bohemia and German Emperor, was his son Wencislaus who ruled as King of Bohemia from 1378-1419, but served as Emperor only until 1400. Under Charles IV, Imperial documents and correspondence began increasingly to be written in German, rather than the traditional Latin. The need to develop a competent staff of Imperial secretaries was not the least reason for founding the German University of Prague. - Translator's Note.) During Wencislaus's reign, the native-born Czechs struggled against the German colonization of their land and agitated for greater representation in the civil and ecclesiastical administration of Bohemia. The struggle finally led to that suppression of the German element at the University of Prague whichclosely linked with the name of Johannes Huss-brought in its train a great deal of misery to the country, which had become prosperous under German colonization, and led to the almost total reduction of German pre-eminence in a large segment of the country, particularly in the many cities founded under it.

We do know that Huss, in his Humanistic endeavors and his Church reforms, was influenced by Wycliff. From England, too, our poet had received the prototype for his work in William Langland's allegorical poem Piers Plowman. But the Plowman of Saaz, both in conception of the problem as well as in artistic execution, far out-distances the allegoric-mystical work of the Englishman. 
The lament for the deceased wife and the wrestling with the unfathomable riddle of death is the substance of the work. The author clothes it in the form of a disputation with Death. Death is summoned before the tribunal where the widower wants to bring to account the robber and murderer Death as the despoiler of the land and, thus bring about his downfall. God is the supreme judge and as such, in the thirty-third chapter, renders His judgment: Death, as the agent of God on Earth, is allowed to retain his booty.

Thus, we see that it is the profound problem of dying and the reality of death in the world which this German poet of over 500 years ago has tried to examine and resolve. On the face of it his philosophy is incapable of resolving the problem-but only apparently so. The poet who wrestles with the mystery of death with all the wisdom of the Church and Antique philosophy-in the twenty-third and the thirty-second chapters (the concluding words of Death) -, points out what for man must remain the only possible solution: Love is more powerful than death; in the heart of the husband she has left behind, the wife cannot die, she remains his forever. Man can overcome the awesomeness of Death only through an active and honorable life, through inner peace and a clear conscience.

Our author is first of all a learned man. Indicative of the change in thinking is the fact that he does not, as his age still did, call on Church authorities as witnesses but, rather, on Pagan philosophers. Only the Bible itself does he deem worthy of quoting. Thus he marshals his arguments from the wisdom of Antiquity; Plato, Aristotle and Seneca are his authorities in the dispute and he is comforted by the Platonic theory that all dying is merely a changing into another existence. Who, in the face of such thoughts, can fail to recognize the profound importance of this early German masterpiece? The poet has assimilated thoroughly the knowledge of his time and disposes of it freely and independently of dogmatic teaching; he is acquainted with all the known Antigue philosophy and quotes-albeit, not always from prime sources-thoughts from its significant representa- 
tives. They are his guides toward a positive world view, a mundane viewing of life which is a far cry from the ecclesiastical asceticism of the Middle Ages. Here, the new direction, embedded in the Renaissance, toward a joyous outlook on life is proclaimed, while Death becomes the bitter denier who sees in life only the end, that which is helpless, perishable and evil.

But Death, too, is a grandiose figure. He is the Lord of Earth, invested by God in order to maintain the balance of nature. All men are to him worthy to die and life exists only for the sake of dying. He is the king to whom all living things must pay tribute. Full of derision he looks down upon the pain-tormented heart of Man and the intellectual striving of mankind. But he, too, must bow before the sublime majesty of God-for even Death is only a vassal of God, the Liege Lord.

One other thing becomes clear as the titanic struggle between the Plowman and Death unfolds: The widower John is not only the chief scribe of Saaz, he is also the spokesman of mankind who wrestles with the riddle of death and, in repeated outbursts of despair, laments the destruction of warm, creative human life. Thus the poem becomes mankind's cry of despair against the blind hand of Death. Death, himself, acknowledges this relationship of the plaintiff for, again and again, he recognizes in the pleading widower the figure of Adam, the son of Man, whom he has met-and annihilated-so often in the shape of the seeker after knowledge and the doer of heroic deeds. To be sure, he only sneers and jeers at this aspiration of Man to increase in knowledge and deed, for he is the negator, the reflection of Satan.

These are only a few facets of the deep content of the dialogue but they will suffice to make clear to us the magnitude of conception and allow us to admire the poetic power and talent of its author. Nor dare we forget that the poet plays both roles, that of Man writhing against Death and that of the cold destroyer of all life. On either side he exerts to the utmost his powers of thought and feeling and in doing so finds for himself repose and a resolving final chord in that magnificent closing prayer of adoration, so rich in feeling, in thought and linguistic fullness. 
The work is also a masterpiece in its construction, in the legal argumentation before the Tribunal of God, in its poetic composition and-last but not least_-in the linguistic and stylistic development which it shows. We need only to examine the first chapter for its forceful speech, its wealth of words, the symmetrical, harmonious structure of its sentences and expressions, to realize what linguistic barrenness, stylistic threadbareness still pervades so many contemporary and later poetic works which histories of literature often praise highly. And, like this first chapter, almost all the others are equally rounded artistically and endowed with a force and fullness of speech that arouses our admiration for the mastery of the poet. In cadence also it is true German speech; not the frightfully arabesque book-German (into which the Chancellery style, developed at the University of Prague, finally deteriorated.-Transl. Note.). With all its finely balanced artistry, the work is replete with down-toearth colloquial verve. With all his learnedness, the poet nevertheless draws from the rich well of the vernacular of the people and is well acquainted with its everyday customs, as well as with the rituals of jurisprudence and knighthood of his day.

The Bohemian Plowman has the advantage of being a prose work. Its speech, unfettered by rhyme, flows freely and easily without hindrance from the traditional phrasing of versification. Yet, withal, this singular prose work is truly poetic in every word and phrase, so that in its Early New High German form almost every sentence has feminine rhythmic endings (klingender Versschluss), many of which could not be preserved in the Modern High German transcription (nor in the English translation, of course.-Trans. Note). Last, but not least, it must be observed that the Bohemian Plowman is the first literary work which introduced, and thus diffused, into German literature, the New High German written language which had been developed in the Bohemian Chancellery of Charles IV.

My transcription into Modern High German renders the meaning and wording of the old text faithfully in accordance with the diplomatic text which I, in collaboration with Konrad Bur- 
dach, have published with Weidmann in Berlin (1917) and can, thus, be taken as completely accurate and reliable. My chief aim was not to falsify the work, and to avoid any watering-down as well as any embellishment of the same. To the reader, receptive to intellectual riches and poetic and linguistic beauty of form, there is herewith presented this astonishing achievement of early German writing.

-Alois Bernt. 


\section{The 㹱latututff}

Grim Destroyer of mankind, vengeful Persecutor of the whole world, frightful Murderer of all men, Thou, Death, be cursèd! May the God who created Thee hate Thee; may harm a thousandfold meet up with Thee; may misfortune dwell mightily with Thee: Mayst remain dishonored for ever.

May fear, need and misery not leave Thy side wherever Thou abidest; may sorrow, sadness and grief accompany Thee on all Thy errands; may bitter assault, shameful trepidation and ignominious enmity press heavily upon Thee and unremittingly: May heaven, earth and sun, may the moon and the stars, the oceans and the waters, mountain and field, valley and meadow, the abyss of hell and all that which hath life and motion be to Thee hostile and resentful and curse Thee without end!

Mayst Thou drown in wickedness, welter about in pitiful misery and remain banished in the outspoken and irreconcilable outlawry of God, of all men and of every created being for all the days to come!

Shameless wight, may Thy evil memory live and abide without end, may dread and fear not cease to dog Thy footsteps wherever Thou wanderest or takest up Thy abode:-From me and every being to Thee a Woe! cried out with wringing hands!

\section{2. 羿eath}

Hark, hark, hark, what new and strange proceedings are these! A frightening and hitherto unheard-of suit at law assaileth Us; whence this cometh is wholly unknown to Us. For hitherto we have always remained immune to threats, curses, cries of shame, wringing of hands and assaults of any kind. Nevertheless, belovèd Son, let Us hear who thou art and make known what harm hath come to thee through Us, why thou treatest Us so unseemly. For never had We been accustomed to such, even though We have cut great swaths through the hedgerows of many wise, nobly born, handsome, powerful and ambitious people to the great benefit of widows and waifs, to land and people. 
Thou actest as one determined to press his suit and as though lawful distress drove thee to it. But thy complaint is surely without cause so that We believe thou desistest not for the sake of noise and speechmaking. But if thou be raging mad, or blinded, or in some manner deprived of reason, then wait, hold off and be not over rash with thy cursing; lest, with overdue repentance, thou comest to harm. Fancy not that in the least thou couldst diminish Our sublime and overriding power.

But now name thyself-and do not hold back in what matter we have done thee such grievous wrong. Justified without a doubt shall we be in thine eyes, for lawful is all Our doing. We know not why thou accusest Us so rashly!

\section{The 独latuttiff}

A plowman I call myself; from the bird's feather I fashion my plow, and dwell in the land of Bohemia. To Thee I shall always remain hostile, oppose Thee and hate Thee for Thou hast torn from me with frightful hands the twelfth letter of the alphabet, the sum total of my joys; Thou hast weeded mercilessly from my heart's garden the lithesome flower of my ecstacy; with evil trickery Thou hast stolen from me the mainstay of my happiness, my chosen turtle dove; Thou hast committed irreparable robbery on my person! Consider for Thyself if I be not rightfully angry and enraged and justified in my complaint: through Thee have I been robbed of a joyous life, done out of my days of happiness and deprived of the possession that warmed the cockles of my heart. Gay and happy was I ere this at all times; short and pleasurable was for me every hour of the day and night, filled alike with mirth and relish, and every year a year of grace.

Now I am being ranted at: Pack thyself hence! With somber draught, on a dead branch I sit, sorrowed, darkened in spirit and withering away, shedding tears without surcease. Thus the stormy gusts whip me along, I wallow in the troughs of the wild sea, while giant waves break over me, and cannot find a firm 
hold for my anchor. Therefore shall I cry without surcease: Upon Thee, Death, curses!

\section{4. 想eath}

Wondrously strange seemeth to Us this unheard-of assault, the like of which hath never happened to Us. Art thou a plowman, domiciled in the land of Bohemia, then it seemeth to Us thou doest Us grievous wrong, for long is the time since We have carried on serious work there, other than, of late, in a fortified and beauteous city rising powerfully on a hill. Four of the letters of the alphabet have woven her name: the eighteenth, the first, the third and the twenty-third. There We ended Our work of mercy with an honorable, mirthful daughter of man; her letter was the twelfth. She was, forsooth, brave and without blemish, for We were present when she came into the world. At that time fair Lady Honor bestowed upon her a laprobe and a wreath of virtue; both, wreath and robe, she brought back to the grave untarnished and untorn. Her witness and Ours is He Who knoweth all hearts. Of clean conscience, pleasant, faithful and, above all, true and kind was she to all men. Forsooth, rarely hath it been Our lot to lead home a woman of such fair countenance and steadfast mind. Lest she be the one thou speakest of, We know of nary another.

\section{The 坊laintifff}

Aye, Sire, I was her spouse, she my belovèd wife. Thou hast taken her from me, the charming jewel of mine eyes; gone is my protecting shield against adversity, lost my soothsaying wishing wand. For now she hath yielded her breath. Here, poor plowman, I stand alone; vanished is the bright star of my heaven; gone to its rest the sun of my salvation, never to rise again. Never again shall my pulsating morning star guide my way; paled is its gleam; naught is left me to drive away sorrow; somber night stretches ever before mine eyes. Methinks that nary a thing shall ever render me real joy again, for the proud banner of my bliss hath fallen away to my sorrow. 


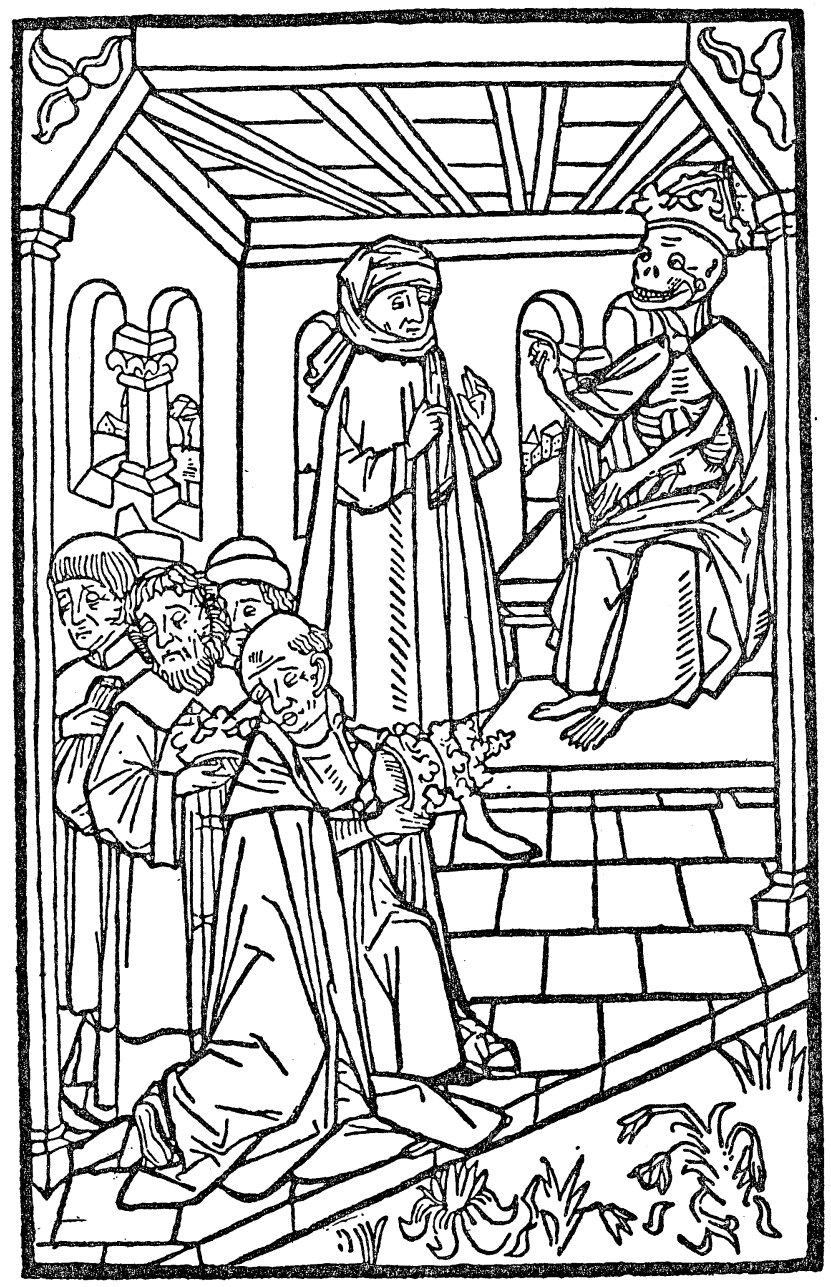


Cry havoc! And mercy! Called from the bottom of my heart upon the year, upon the day of misfortune and upon the painful hour in which my steadfast diamond was broken, in which my sure-guiding pilgrim's staff was wrung, without mercy, from my hands, in which the way was barred for me to the quickening fountain of my youth and my salvation.

Alas and without end, may woe without surcease, ignoble foundering, sudden fall and eternal abyss be Thine inheritance on Earth, oh Death! Filthed over by heineousness, greedy after shame, bare of all honor, with teeth agnash, mayst Thou die and suffocate in Hell! May God take Thy power from Thee and scatter it like dust! Lead, without end, a blasphemous existence!

\section{E. 想eath}

A fox struck a sleeping lion in the cheek: hence his pelt was torn; a hare pinched a wolf: as of today he's still tailless; a cat scratched a dog who wanted to sleep: ever since she must endure his enmity. In like manner thou wishest to carry on with Us. But We believe: slave remains slave; master, however, master. We wish to prove to thee that We well know how to weigh, judge and act rightly in the world, respect no patent of nobility, esteem not consummate learning, pay heed not to beauty and never lay either talent, love and sorrow, nor age, youth or aught else into the scale. We do as the sun doeth which shineth upon the good and the bad. Into the orbit of Our power We draw the good and the bad.

All the masters who know how to curb spirits must deliver up and surrender to Us their spirit; the elfin sprites and witches cannot prevail against Us, it availeth them naught that they can ride on goats or broom sticks; the physicians who know how to prolong the lives of others must, in the end, become Our prey, neither healing root nor herb, nor salve, nor apothecary's powder can help them aught. Were We to give account only to butterflies and grasshoppers about their mowed-down generations they would fain be satisfied with Our reckoning; should 
We, however, because of enmity and love or sorrow spare men's lives? Forsooth, then all the empires of the world would soon be Ours, all kings would set their crowns upon Our head, their scepters would they lay into Our hands, aye, the Pope's own throne with his triple crown would be in Our power today.

Be done, therefore, with thy cursing, relate not fancied tales with thy blabbering mouth, hew not the wood above thy head, lest splinters fall into thine eyes!

\section{The 㖧launtiff}

Could I but damn, could I but scold, could I but scoff that Thou wouldst be worse off than blighted, Thou wouldst well be served for Thy snide doings unto me. When great wailing followeth deep sorrow, wouldst say I acted not humanly if I lamented not such divine and all-excelling gift which none but God alone can grant. Forsooth, sorrow shall be my lot for evermore: flown thither is my renownèd falcon, my wife so rich in virtue. By rights must I lament, for she had been of noble birth, endued with honor, of vigorous and pleasing prestence superior to all her playmates, truthful and discreet in all her speaking, chaste in her doings, generous and gay to her acquaintances-my speech must cease for lack of words to tell of all her virtues which God, Himself, to her assigned; Lord Death, Thou know'st them full and well.

And for this heartbreak will I, with full right, demand account of Thee. And, verily, were there a thread of good in Thee, Thou wouldst Thyself have pity! I shall turn my face from Thee, say no good of Thee, with all my strength be hostile to Thee evermore: the whole of God's creation shall be my helpmeet to work against Thee; mayst Thou be hated and envied by all that dwelleth in heaven, on earth and in hell.

\section{密。想ath}

The thrones of Heaven to the good spirits, the abyss of Hell to the evil ones: the reaches of the Earth God hath assigned as heritage to Us. Heaven accordeth peace and reward for virtue, 
to Hell belongeth pain and punishment for sin: the round of the Earth and the mains of the ocean with all they contain have been allotted to Us by the Mighty Ruler of the world with the command that We should root, stamp and weed out all that is superfluous. Consider it, thou Fool, test it and etch it into thy reason with the needle of the spirit and thou wilt confirm: Had We, from that day forth on which the first man was puttied from clay, never weeded out mankind on earth, animals and crawling forms in wilderness and lonely heath, the increase and profusion of slippery and scaly fish in the water-with all the gnats, could anyone exist? With all the wolves, wouldst dare leave thy house? One man would devour his neighbor, one animal the other, every living creature some other, for they would lack nourishment, the Earth would be too small for them. A fool he, who would lament then what is mortal. Let be and desist! The living to the living, the dead to the dead as it hath always been. Bethink thyself better, foolish man, whereof thou wouldst complain!

\section{The 犯lañntiff}

Irretrievably have I lost my greatest treasure. Shall I then not be sad and brimmed with sorrow when, robbed of my joy, I must live on till my own death! May the gentle God, the mighty Lord, avenge me on Thee, wicked Dispenser of Sadness!

Thou hast deprived me of all rapture, robbed me of blissful days, stripped me of great honor. For great honor I enjoyed of yore while the good, the pure, the radiant one cuddled her children, come into the world in a clean nest. Dead is the hen that reared such chicks. Oh God, mighty Lord, what lovely sights my eyes beheld when, honorably, she walked along with comely gait so that people looked at her with love and spake: "Thanks, praise and honor to the good woman, may God grant her and her nestlings every good!" Would that I rightly knew how to thank God for this, forsooth, I would have cause enough. What other poor man hath He so richly endowed?

Let others say what they might: he, to whom God hath 
granted a pure, chaste and comely wife, possesseth a gift truly called gift, a gift beyond all others in the world. Oh Thou, Almightiest Count of Heaven, how well off is he to whom Thou hast joined a pure, unblemished spouse! Rejoice, honorable man, over a chaste wife; rejoice chaste woman, over your honorable husband: May God grant joy to both of you! What knoweth thereof the fool, who hath never drunk from this fountain of youth? Yea, even though great violence and heartbreak was done unto me, nevertheless, I thank God from the inmost recesses of an undissembling heart that such consummate wife hath been my possession. To Thee however, wicked Death, all mankind's Antagonist, may God bear enmity, time without end!

\section{0. 聚eath}

I sense it in thy words: thou hast not drunk from Wisdom's fount. Thou hast never looked into the workings of Nature; never cast a glance into the interrelation of the sticks and stones of this world; never perceived the earthly change of things: an uncomprehending little whelp art thou. Behold how the voluptuous roses and the strong-smelling lillies in the garden, how the strength-giving herbs and joy-dispensing flowers of the fields, how the age-defying rock and the tall-growing trees in the wild pasture, how the strength-burgeoning bears and the powerfully strong lions of the awesome wildernesses, how the tall, renowned heroes, the swift, intelligent, highly learnèd men, masters of every undertaking; how, in fact, every earthly creature, no matter how clever, how much alive, how long it can hold itself erect, how long it can endure: all must ever come to naught. And if now all humankind that hath ever been and is still to be born, must pass from being unto not being, why should the unimpeachable woman whom thou lamentest be singled out and remain immune so that with her it happen not as with the others and all the others as with her? Thine own self shall not escape Us, as little as thou thinkest thereon this day. Each one in his turn! every last one of you must say.-Thy charge is vain and futile, nor can it help thee aught; it issueth from a witless mind. 


\section{The 洺laintiff}

In God, who is Thy Lord and mine, I rest my trust that he will protect me against Thee and avenge in direst fashion the evil deed Thou hast so foully done me. A charlatan, Thou speakest before me, mingling truth with falsehood, intent to wrench out of mine eyes, my head and thought, the frightful sorrow of my senses, of my reason and my heart. But it availeth Thee naught, for I remain asmart with the bitter loss which nothing can restore.

For, day and night, she unweariedly was my restoring medicine for all woe and adversity, God's servant, guardian of my will, caretaker of my body, sentinel of her renown and mine. Whatever was entrusted to her was ever rendered back whole, pure and unharmed, aye, even increased. Tempered demeanor, provident doing and wise action dwelt forever in her realm; Modesty ever held the mirror of honor to her eyes; God was her neverfailing counsel. For her sake He was also gracious and favorful to me: the honor of our house, so pure, had earned and deserved that of God. Reward and gracious meed give unto her, Thou benevolent Disburser, Almoner of faithfulness, most rich Lord! Be to her more merciful than I could wish! Alas, alas, alack, shameless Murderer, Sir Death, wicked Iniquitator! Be the henchman Thy judge and, by Thy speech, bind Thee to the block.

\section{2. 羿eath}

Couldst rightly weigh, test, calculate, or think, thou wouldst not let such words issue from thy weak head. Thou cursest and prayest without insight and prompting. What good is all such foolish doing? We have said it before: All that is artfully fashioned, nobly born, honorable, brave and otherwise excellent, in fact, all that hath life must perish at Our hands; and, yet, thou brayest like a jackass and maintainest that all Thy happiness depended on thy chaste and good wife. If, according to thee, happiness depend on woman, We could, indeed, give thee counsel how to remain happy. But beware that it may not turn into unhappiness. 
Do tell Us, though: When thou tookst unto thee the renowned woman as thy wife, didst find her excellent, or hast thou made her so? If thou didst find her already excellent then cast about with circumspection for, no doubt, thou couldst then find many another excellent and chaste woman on earth, one of which would suit thee in wedlock. But hast thou made her all-excelling, then rejoice: thou art the living master craftsman who knoweth full well how to fashion and upbring another excelling wife.

But let me remind thee of one further thing: The more love hath been thy share, the greater will sorrow be thy part; hadst abstained from love before, thou wouldst now be spared all sorrow; the greater the happiness of having tasted love, the greater the grief of missing it. Wife, child, riches and every earthly good must bring a little joy at first, but greater sorrow in the end. All love on earth must turn to sorrow: Sorrow is love's expiration, sadness the end of joy, upon hap must follow mishap; the end of will, ill-will; such is the course of all human affairs. Learn to know it better, if thou wouldst be clever of speech.

\section{The 诋laintifff}

Full well know those who suffered harm: insult followeth in injury's train. In like fashion Thou abusest me, the afflicted man. Thou hast disabused me of joy, accustomed me to sadness and, as long as God shall permit, I must suffer it from Thee. However foolish I may seem to Thee, however little wisdom I may have garnered from the learnèd masters, this much I know full well: That Thou art the robber of my honor, the thief of my joy, the plunderer of my bliss, the quencher of my' ecstacy and the ravager of all that gave me and assured me joyous existence. Whereof shall I rejoice now? Where seek my comfort? Whither fly for refuge? Where shall I find asylum and cure? Where find true counsel? Gone is gone. All my joy hath vanished afore its time; too early hath it passed from me; all too soon Thou hast torn her away from me, the 
lovely one so faithful, and mercilessly hast made me widower and my children orphans.

Helpless, alone and filled with sorrow, I remain unrequited by Thee: neither amends nor restitution for great harm done could ever come to me from Thee. How is it therewith, Sir Death, Adulterer of all men's marriage bed? Of Thee no one can expect good; after foul deed Thou givest satisfaction to nary a one; for evil done Thou wouldst give no recompense. I note it well : Mercy dwelleth not within Thee; accustomed art Thou only to cursing, and clemency knowest Thou nowise. Such kindness as Thou showest Man, such favor as Thou grantest, the compensation that Thou payest, the end which Thou preparest Man, may all these, in like measure, be sent to Thee by Him who in His hand holdeth both, Life and Death.

Ruler of the Heavenly legions, reimburse me for my fearful loss, the great harm, the bitter affliction, the miserable crime! Avenge me thereof on Death, the arch-rogue, oh God, Avenger of all evildoing!

\section{4. 想eath}

Useless words are not worth better coin than silence. For upon foolish speech followeth quarrel, upon quarrel enmity, upon enmity unrest, upon unrest outrage, upon outrage the day of pain and upon the day of pain belated rue must come to every muddled man.

Thou challengest us to battle. Thou pleadest cause that We have done thee harm in the person of thy much belovèd wife. We have dealt with her graciously and with mercy: in the joyous years of youth, of splendid form, in the prime of life, in the best esteem, at the most opportune time, in unblemished repute, We have taken her tenderly into Our favor. Such hath been lauded, such hath been desired by all wise men when they spake: "T'is best to die when it's best to live!" He hath no easy death who desireth death; he hath lived too long who calls on Us for the sake of dying; woe and privation to him who is bent double with the burden of age: with all his possessions he needs be called poor! 


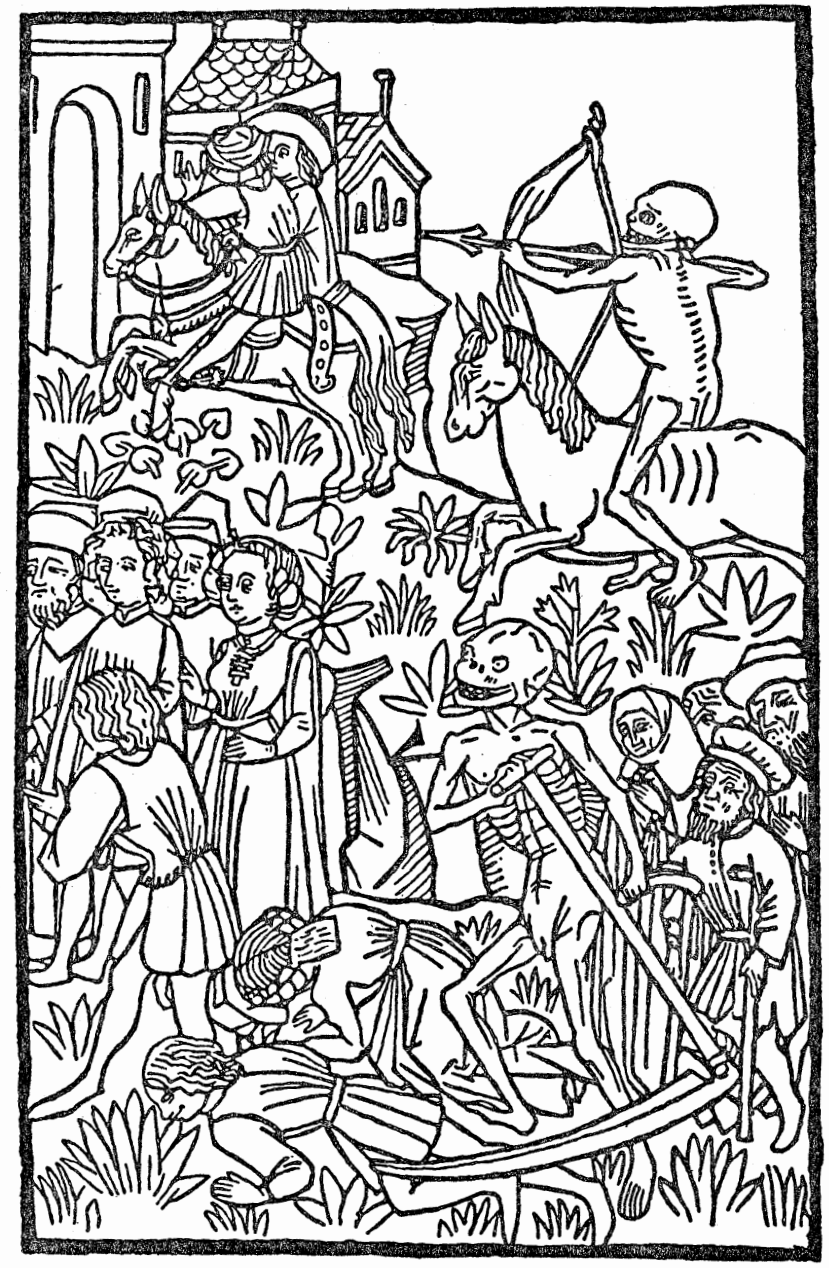


In the year when Ascension's highway stood open on Chain Feast Day of the Keeper of the Heavenly Gates, when from the beginning of the World the years had been counted to 6599 , We ordered the blessèd mortal, while in childbed, to leave this short be-tinselled misery called life in the knowledge that, in reward and through His grace, she would enter upon God's inheritance in eternal joy, to everlasting life and infinite rest.

Spiteful as thou art to Us, we would wish thee and favor that thine own soul were with her in the heavenly mansions, thy body however, united with her in the narrow house. Bondsman would We fain be for thee: her store of good deeds would stand thee in good stead. Therefore be silent and put a bridle to thy tongue. As little as thou canst take the light away from the Sun, the cold gleam from the Moon, the heat from the fire, or the wetness from the water, as little art thou able to take from Us Our power!

\section{The 狂laintiff}

Of flowery speech the guilty hath ever need. Thou actest according to the saying. Sweet and sour, gentle and harsh, Thou art accustomed to show Thyself to those Thou art bent upon to defraud. That much hath been revealed on me. However much Thou wouldst encloak Thyself, I do know this: that because of Thy blustering displeasure I must fain be wanting my honorable and comely wife. Also do I know that, other than Thee and God Himself, no other is possessed of such great power. But t'is not God who hath visited me thus: for had I sinned against His law-as, alas, hath happed all too oft-He would have wreaked vengeance on me, or my immaculate spouse would have righted it for me. Thou alone art the evil-doer. Therefore, I would fain know who Thou art, what Thou art, where Thou dwellest, whence Thou comest and for what Thou mightest be of use that Thou possessest so much power to have challenged me so cruelly without forewarning of hostility, to have laid waste my joy-filled green, undermined the tower of my strength and caused its downfall. 
Oh God, Comforter of all hearts in distress, comfort and recompense me, poor, sorrowed and wretched man left to his own devices! Impose punishment, oh God, exact accounting, put an end to him and destroy grim Death who is Thine enemy as much as the enemy of us all! Oh Lord, in Thy whole creation there is naught more gruesome, more eschewable, more harmful, more bitter, more unjust than Death! He afflicteth and bringeth confusion to Thy earthly domain; he'd rather take the fit than the unfit; the harmful, the old, the sick, the useless he often leaveth behind and taketh ever away the good and the able. Oh Lord, sit in judgment on the false judge!

\section{IÉ. 咕eath}

Men deprived of reason call good what is evil and evil what is good; thou actest like them. Thou bringest action against Us for false judgment and doest Us injustice therewith. Of that We wish to proffer thee proof.

Thou inquirest who We be: We are the hand of God, the Lord Death, an honest working reaper. Brown, red, green, blue, grey, yellow, indeed, flowers and grasses of every glistening hue, We mow down in turn without regard to sheen, strength or other excellence. We do not spare the violet for its beautiful color, its rich fragrance, nor its delicious juice. Behold, that We call justice. Romans and poets have adjudicated this to Us according to Our rights and just dues because they knew Us better than thou dost.

Thou questeth what We be: We are nothing and yet are something. Nothing, because we possess neither life, nor essence, nor form, are not spirit, nor visible and palpable. Something, because We are the end of life, the end of being, the beginning of non-being, the cleavage between the two. We are a thing which bringeth all men to their downfall. The great giants topple before Us, all beings which have life must be transformed through Us. With good reason we stand impeached of that.

Thou askest Us where We abide: Our abode is not ascertainable, for We wander to the ends of the world. Our likeness, 
though, was found painted on the wall of a temple at Rome as a man riding blindfolded on an ox, carrying in his right hand a cleaver and in his left a shovel; with these he fought astride the ox. Against him were arraigned a large assembly of people fighting, shooting, throwing, all kind of people, every man with the tools of his trade, among them even a nun with the psalter. They struck and pelted the man on the ox and meant Us, yet were they conquered and buried all by Death. Pythagoras compared Us with the image of a basilisk-eyed man at whose sight every living creature must die.

Thou askest whence We came: We trace Our being from the earthly Paradise. There God created Us and called Us by Our rightful name when he spake: "On the day that thou eatest of the fruit of this tree thou shalt die of Death." Hence We sign Our name thus: "We, Death, on Earth, in the Air and on the Waters of the Sea, Lord and Ruler."

Thou askest of what use We be: Thou hast been told afore that We bring the world more benefit than harm. Desist therefore, be content and thank Us that thou hast been dealt with so mercifully by Us.

\section{The 狂latintiff}

Old men strange stories tell, learnèd men unknown tales relate, well-traveled man and he whom no one dare gainsay make stories out of whole cloth: for who could refute them in matters not within the ken of man. And since Thou art such an old man we give Thee leave to fabulate.

However, if as a reaper Thou claimest descent from Paradise and aimest to do right, Thy scythe cutteth unevenly. Right vigorous flowers it rooteth out, the thistles it letteth stand; weeds abide, the good herbs must perish. Thou maintainest that Thy blade doth cut each in its turn. How come then that Thou leavest unharmed more thistles than good flowers, more hawkweed than camomile, more wicked men than good ones?

Tell them off to me, point at them with Thy fingers: Where are the capable, honorable men of yesteryear? Methinks, Thou 
hast them all. With them too is my beloved; dust only and ashes are left for me. Whither have gone they who dwelt on earth and conversed with God and earned favor, mercy and grace from Him? Whither are they who, while dwelling on earth, circumnavigated the stars and computed the planets? Whither the thoughtful, the masterly, the honest, the vigorous men of whom the chronicles know to tell so much? Thou hast murdered them all, together with my turtle dove; the lesser ones are left only among the quick.

And whose the fault? Daredst acknowledge the truth, Sir Death, Thou wouldst name Thine own self. Thou maintainest staunchly that Thou judgest rightly and without favor, that the thrust of Thy blade cutteth each after the other. I was present and saw with mine own eyes two mighty armies-each having well over three thousand men-contending with each other on a green heath. They waded in blood up to their calves. Thou wast buzzing and whirling mightily among them from one end of the field to the other. Thou didst kill many in these armies, yet, Thou also didst let many a one stand. More masters than servants, methink, saw I fall to the ground. Elsewhere Thou didst claw one out of the midst of the others as over-ripe pears are plucked from a basket. Dost call that mowing rightly? Wouldst call that judging justly? Is that the straight math Thy scythe doth cut?

Well, then, dear children, come hither, come ye here! Let us ride out to meet Him and offer honor and speak in praise of Death who meteth out such fair justice! God's justice can hardly be as fair!

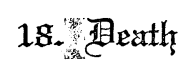

$\mathrm{He}$ who doth not understand matters can hardly talk about them. Thus it has happened unto Us. We did not know that thou wast such an excellent man. We had known thee for a long time but We had forgotten about thee.

For were We not present when Dame Sybil left thee her wisdom, when King Solomon on his deathbed willed thee his 
sagacity, when God assigned thee all the power with which $\mathrm{He}$ had invested Moses in Egypt, when thou tookst the lion by the leg and hurl'dst him against the wall. Forsooth, we saw thee count the stars, compute the sands of the ocean and its fishes, determine the number of raindrops. We assisted with pleasure at the race which thou ranst with the hare. At Babylon, We saw thee officiate in great honor and dignity at the Sultan's banquet as foretaster and cupbearer and when, before King Alexander, thou didst bear the banner with which he conquered the Earth, We looked on and did not begrudge thee the honor. When, at the Academy at Athens, thou didst dispute with and wast victorious in thy knowledge over the exalted and erudite masters who could discourse most profoundly about even divine matters and understood many things, We rejoiced in particular; and when thou didst instruct King Nero in acting justly and in showing forebearance and patience, We listened to thee with glee. We were amazed how thou didst transport the Emperor Julius Caesar across the wild sea in reedy vessels in the face of every stormy blast. In thy workshop We watched thee fashion fine raiments from rainbows and skillfully weave them into the shapes of angels, birds, four-footed beasts and fishes of all kind; among them even the owl and the ape were warped into the woof. But We laughed most heartily and became boastful about thee when We saw thee sitting at Paris on Fortune's wheel, executing thy dance on the cowhide, practicing black magic and banishing devils into a grotesque glass. And when God called thee into His council to advise Him on the fall of Eve, We were thoroughly convinced of thy great wisdom.

Had we recognized thee earlier, We would have given in to thee. We would have left thy spouse and all of mankind alive for all eternity. This We would have done solely in thy honor, for thou art verily a most clever jackass! 


\section{The 犹laintiff}

Oft, for the sake of truth, men must endure mockery and vile abuse. Much so it haps with me. Thou laudest me for impossible things, thinkest up unheard-of feats and ventest Thy spleen on me. Verily, Thou hast treated me basely and I am sorely aggrieved thereof. If I then speak of it, Thou art hateful and wroth toward me. But he who doeth evil and will not bend his pleasure, nor suffer and accept reproof, let him have a care lest enmity be his reward therefor.

Pray follow the example I have set Thee: no matter how unceasingly knavishly, fouly and unjustly, Thou hast toyed with me, I have even so suffered it and not avenged it as well I ought have. Even now I would aim to be the better of us two, for if I have done Thee an injustice or spoken unseemly, pray, advise me thereof; I shall gladly and willingly make amends. But if such be not the case then do Thou make amends for the harm done me, or teach me how I may be restored from my great heartbreak. Forsooth, no man hath ever been dealt with so meanly. Yet would I have Thee take note of my forebearance. Either Thou undoest the wrong done to me, to my children and to her who fended away sorrow from me, or Thou comest in this matter with me before God Who is the righteous judge of me, Thee and all the world. Thou couldst easily entreat me: I would fain leave the matter to Thee. I have had trust in Thee that Thou wouldst perceive Thine own injustice and give me satisfaction for the base evil done me. Act with insight, else the hammer shall strike the anvil, flint against flint, come what may!

\section{0. 羿eath}

Through kind speech people are mollified, understanding leadeth men to peace, forebearance bringeth them honor-angry man cannot discern truth. Hadst thou, ere now, spoken to Us with good grace we would, with kindness, have instructed thee that thou doest wrong to lament and becry thy spouse's passing.

Hast not heard of the philosopher who, in his bath, wanted 
to end his life? Or read in his books that no one should lament the dying of mortals? If thou knowst it not, then know it now: As soon as he is born, man has already received the earnest of his death. The end is the twin of all beginning. He who was sent out is in duty bound to return. Against what hath been ordained to happen, no one should lash with the tongue; that which it behooveth all men to suffer, no one should cavil. What a man hath borrowed he also must return. Men live on Earth as in a foreign land. From being they must come to not being. On swift feet doth human life hasten on: now alive, done at the flip of a hand. - To make short shrift: Every man oweth Us a dying and his inheritance is death.

If, perchance, thou bemoanest thy wife's youth, thou doest wrong: For as soon as a man cometh into life he is old enough to die. Mayhap Thou deemest old age a precious good? Not so! for it is replete with illness and affliction, misshapen, cold and displeasing to all. It is good for naught and in no wise of benefit: Over-ripe apples are prone to fall into slosh and pears into the slough.

But if thou lamentest her beauty then thou actest childishly: For all human comeliness must be destroyed either by death or old age. All rosy-hued lips must grow pale, the cheek's ruddy glow turn pallid and bright eyes dim. Hast not read how the philosopher Hermes teacheth that a man should beware of comely women and sayeth: "What is beautiful is hard to hold on to in spite of daily care because others covet it, but what is loathsome is not hard to retain because it is displeasing to all." Desist therefore! Lament not the loss which thou canst not undo!

\section{The 坊launtitff}

Wise man accepteth admonition gratefully, I've heard the sage men say. Thy admonition, methinks, is meet and fair. If, then, a good chastener be also a good mentor, advise and enlighten me how I shall banish, etch and weed out of my senses such unspeakable sorrow, doleful cumber and burdensome bereavement. God be my witness, unutterable heartbreak hath ever been my 
lot since the chaste, faithful and steadfast adornment of my house was torn from me and I was made widower and my children waifs.

Oh, Sir Death, the world ever crieth out against Thee as I do, that never were there a man so vile he be then good for something. Counsel, help and point out to me how I can rent this grievous sorrow out of my heart and how my children are to be repaid for the loss of such an unblemished mother since, else, I shall remain senseless with anger and saddened evermore. And this Thou canst not hold against me, for well do I perceive that even among the unreasoning animals one mate will, out of inborn urge, mourn the other's passing.

Help, counsel and restitution Thou owest me, for Thou alone hast done me this harm. Should such not come about, then-even if God, in His Omnipotence, had nowhere the means for vengeance-it would needs be avenged even if, once again, cleaver and shovel had to be brought into use.

\section{2z. 面eath}

Quack, quack, quack! cackles the goose; one may preach what one may! Thou spinnest thy yarn along the same plumbline ever. We have expounded it to thee afore that one should not lament the passing of mortals. Since matters are as they are and We are appointed tollkeeper to Whom all men must pay toll and surrender their life, why dost set thyself against it? For, verily, he but mocketh himself who undertaketh to do sport with Us.

Let it enter thy brain and lend an ear: Life is created for the sake of dying; were there no life, We would not be, Our Office would have no meaning;-but there would also be no ordered world. Thou art either too full of grief, or reason doth not dwell within thee. Art thou unreasoning, then pray to God that He may endow thee therewith; but if thou art full of grief then have done with, let go and let it be told thee that human life on earth is but a short breath.

Thou pleadest counsel how to sear grief from thy heart: 
Aristotle hath taught thee long ago that joy, sorrow, fear and hope,-these four-bring all the world to grief and especially those who know not how to fend them off. Joy and fear while away time, sorrow and hope spin it out. Whoever doth not drive these four wholly from his heart must evermore be enmeshed in grief through them. Upon joy sorrow, upon love suffering, ever follow here on earth. Love and grief are entwined with each other. The end of one is ever the beginning of the other. Love and grief are naught else than if a man would hold fast something in his heart and not let go of it; even so as with moderation no one can be poor, nor rich with spendthriftness. For contentment and discontent do not cleave to possession, nor indeed to external things, but dwell alone in the heart. He who doth not desire to drive all love out of his heart must, for all time, bear present suffering: Banish, therefore, from thy mind, thy head and heart all thought of love and, instanter, thou wilt be relieved of sorrow. As soon as thou hast lost something and art not able to regain it, act as though it had never been thine own: Thy sadness will leave thee forthwith.

But hast thou no mind to do this, then much grief will still be thy lot. For after each of thy children's death thou wilt encounter heartbreak; after thy death, heartbreak will be their lot, thine and theirs, whenever ye must part. Thou insistest they be repaid for their mother's loss. Canst bring back the years that have passed, words spoken, maidenhood deflowered, then thou art also able to bring back the mother to thy children. We have counselled thee without stint. Canst comprehend it, thou dull pickaxe?

\section{The 狼laintiff}

In due course one perceiveth the truth: taught for a whilelearned a mite. Thy learnèd proverbs are sweet and gay; I've had enough of them. Matters would stand badly with the world, were joy and love, rapture and pastime driven from the world. In this matter I can call the Romans to witness. They practiced it themselves and taught their children to esteem joy highly and, 
in their leisure time, to engage in jousts, tournaments, dancing, running and jumping and all sorts of pleasing pastime, so that, meanwhile, they would be kept from evil-doing. For the thoughts of a man's brain cannot stay idle; the head must at all times think either good, or bad. In sleep even it will not be idle. Were good thoughts, therefore, taken from the head, evil ones would enter. The good ones out, the bad ones in; the bad ones out, the good ones in; this interchange must last till the end of time. Ever since joy, propriety, chastity and other good manners have been driven from the world, the world hath ever been full of wickedness, infamy, treachery, deceit and mockery. Thou canst see that every day.

Were I to punge, therefore, from my thoughts the memory of my cherished wife, evil thoughts would take abode therein; so riuch the more shall I evermore think of her. When great love of heart is suddenly transformed to heartbreak-who can forget it in the blinking of an eye? Only wicked men can do so. Good friends remain rooted in each other's thoughts; neither distant paths, nor long years can separate true friends. If, in the flesh, my wife be dead-in my thoughts she liveth on forever.

Sir Death, Thou must give me truer counsel if Thy counsel is to avail me aught. Else, fluttering bat, Thou must endure further the enmity of birds.

\section{4. 租eath}

Joy, yet not in excess, suffering, but not too much, the wise man shall cherish for gain or loss; thou actest not thus. Whosoever asketh for counsel but inclineth not to follow the advice, cannot well be advised. Our friendly exhortations fail to thrive with thee.

But whether it please thee, or give thee sorrow, We shall bare the truth to the light of day for thee-for all to hear who may lend ear. Thy short reason, thy chopped-off thoughts, thy hollow heart crave to make more of men than they can be. Thou makest man out to be what thou art bent upon. And, yet, he cannot be more-begging leave of all chaste women-than we shall tell thee: Man is conceived in sin, nourished in his mother's womb 
with unclean, unspeakable filth; naked he cometh into the world, begrimed like a beehive. Truly is he an abomination, a veritable spawn, an offal tun, a wormwood, a stench house, a filthy swill tub, a putrid carcass, a mildewed canister, a sack without bottom, a poke full of holes, a flatulent bellows, a voracious gullet, a stinking glue-pot, an evil-smelling puncheon, a deceitful strawpuppet, an earthen still-room, a bottomless firebucket and an alluringly painted tenement of clay. May it be heard by whomsoever: Every roundly made man hath nine orifices in his body from which exudeth such loathsome and filthy dirt, the like of which can scarce be found elsewhere. Thou never layest eyes upon a man ever so handsome, that thou wouldst not shudder if thou hadst the eyes of a lynx and couldst see through his insides. And take from the fairest of women, pull off the tailor's raiments, thou seest then naught but a reedy puppet, a quickfading flower, a short-lived tinsel and soon-crumbling clod of clay. Show me a speck of beauty in all the women who lived but a hundred years ago, excepting the painted ones on walls, and take in return the Emperor's Crown for thine own!

Therefore, let go of love, let sorrow run its course! Let the Rhine course through its bed again like other waters, thou wise Jackass of Dundertown.

\section{The 狂laintiff}

Shame! Shame upon Thee, vile slander bag! How Thou undoest, besmirchest and dishonorest estimable man, God's fairest creature, and withal revilest the Godhead Itself. Now only do I perceive that Thou art full of lies and wert not created in Paradise as Thou claimest. For hadst been set on Earth in Paradise, Thou wouldst full well know that God created Man and all other things in perfection and hath appointed man above them all, given him dominion over all and placed everything at his feet so that Man should rule over the animals on land, the birds in the air, the fishes in the waters and the abundance of the fruits of Earth-as, in truth, he doth. Were man as miserable, evil, and unclean as Thou makest him out to be, verily, then God would 
have created naught that is good and useful. Had God's almighty and venerable hand brought forth such an unclean, flatulent manikin as Thou sayest, He would be a creator in need of reproof. Then also the Word would not stand aright that God hath created all things, and Man above them, in perfection absolute.

Sir Death, desist from Thy useless baying. Thou defilest God's fairest creature. For as to angels, devils, hobgoblins, wraithsthese are spirits under God's compulsion. Man, however, is the most perfect, most estimable, freest work of God's creation. In His own image hath $\mathrm{He}$ created him as God hath said at Creation's dawn.

Where, or when, ever, hath an artificer created so deft and versatile a masterpiece, so small and artful a sphere as the head of man wherein are placed ingenious powers, unknown to any and all demons? There, in the apple of the eye, resideth the sense of sight, the most trustworthy of witnesses, masterfully shaped in mirror-form-to the outermost reaches of heaven's brightness reaching; there, in the ear, the sense of hearing, cleverly concealed behind a thin membrane for the receiving and distinguishing from afar sweet sounds of many kinds; there, in the nose, the sense of smell, going in and coming out through two openings, thoughtfully installed for the pleasurable enjoyment of all delicate and voluptuous fragrance; there, in the mouth are the teeth which grind, day after day, all manners of food; there, too, the thin slice of tongue maketh known every thought of man to his fellow man; there, also, the enjoyable testing ground for the delectableness of every kind of food. Withal, there are in the head the thoughts issuing out of the recesses of the heart with which a man may reach out quickly across the breadth of land and sea and air at will, yea, into the very essence of the Godhead, and even beyond, his thoughts may climb. And man, alone, possesseth that noblest treasure, reason. He, alone, hath the fair form which none but a God would know to create, in which all things meaningful, all art and knowledge, are enshrined with wisdom. Let it be, Sir Death, Thou art the sworn enemy of man and wouldst, therefore, speak no good of him. 


\section{6. 洫eath}

Scolding, cursing and idle wishing, however much there be of them, they cannot fill a sack, no matter how small. Nor can words prevail against a change-ringing blabbermouth. Be it as it may with the claim that man be the epitome of art, beauty and perfection, nathless must he fall into Our snare and be caught up in Our net.

Grammar, the foundation of all proper speech, will not suffice here with her clear and well-set words; Rhetoric, the prolific basis of euphonious speech, helpeth not with her flowery and finely shaded phrases; Logic, the incisive arbiter of truth and untruth, availeth naught with her hidden explanations and labyrinthine paths to truth; Geometry, the appraisor, evaluator and surveyor of the round of earth, is of no use with her unerring measures and proper measurements; Arithmetic, the swift equalizer of numbers, faileth with her calculations, reckonings and agile ciphers; Astronomy, the mistress of the firmament, cannot give succor with the strength of the stars, nor the influence of the planets; Music, the helpful arranger of song and voice, faileth to assuage with her sweet tones and pleasing tunes; Philosophy, wisdom's acre, plowed and sowed crosswise with natural cognition and for the attainment of good manners, helpeth naught with her perfect fruits; Physics, with her many helpful draughts; Geomanty, which with the stipulation of the planets and the signs of the zodiac giveth ready answers to all manners of questions; Pyromancy, the conveyor of swift and reliable prophecy; Hydromancy, which seeketh to foretell the future from the water's waves; Astrology, which interpreteth earthly happenings with celestial events; Chiromancy, which from the hands and the lines of the palm prettily foretelleth the future; Necromancy, which with the sacrificial fingers of the dead and with conjurations mightily tameth the spirits; The Art of secret signs, with its portentious prayers and powerful exorcisms; Augur, he who understandeth the cries of birds and from them truthfully can speak of things to come; Haruspex, who from the smoke of the altar sacrifice interpreteth the future; 


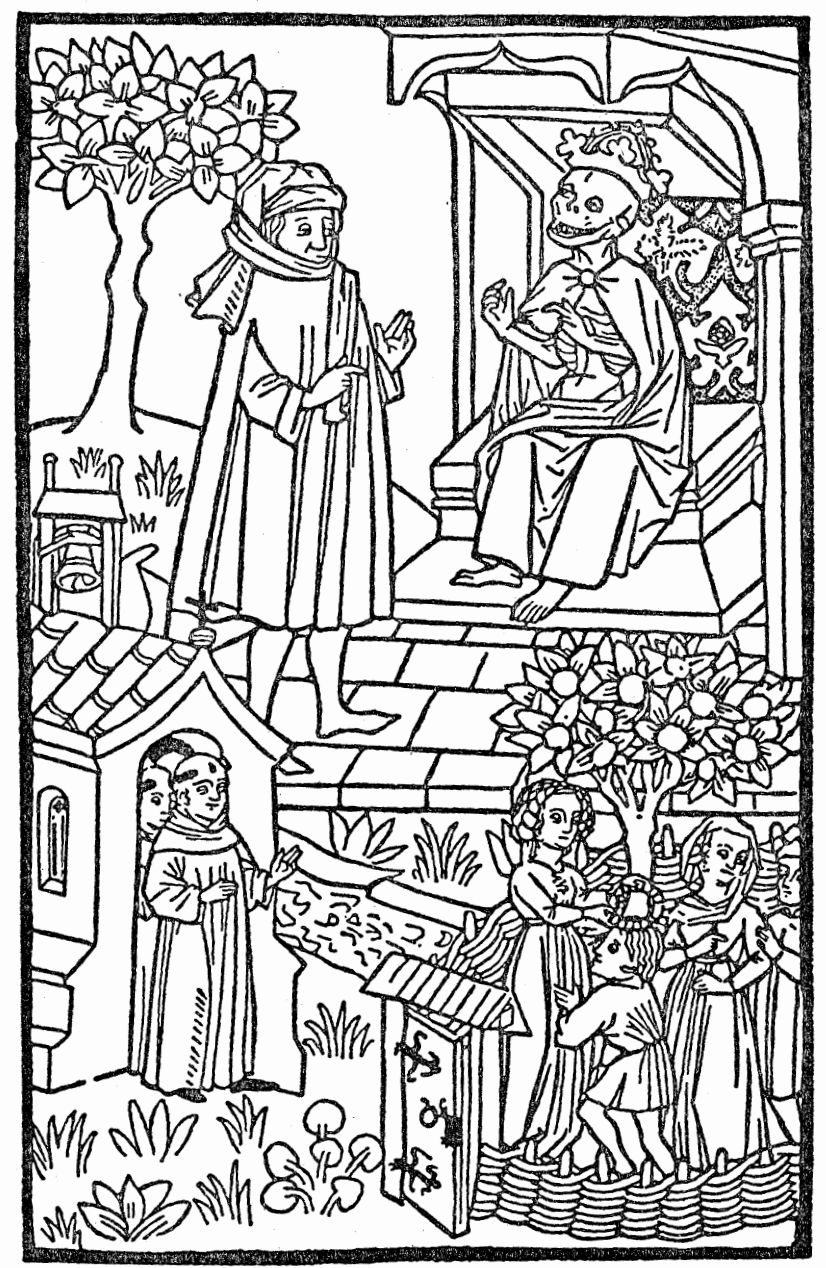


Paedomancy, which from the innards of calves, and Ornomancy, which with the innards of partridges conjure magically; neither can Jurist, the unconscionable Christian, abet with his treading under foot of justice and injustice and with his crooked judgments-for these and many other arts allied with those cited here are all of no avail: Each man must some day be toppled by Us, thrashed in Our fulling-mill, bowled-over in Our whirling barrel. Thou mayst well believe it, thou conceited farmer's dolt.

\section{The 猬laintifff}

Reward not evil with evil; man must exercise patience, thus the teachings of virtue admonish. Onto that road I too shall turn, mayhap that Thou still becomest patient after Thine impatience.

I take it from Thy speech that Thou meanest well with me and advisest me truly. Dwelleth therefore truth in Thee, then give me truthful counsel like one bounden by oath: In what manner shall I henceforth set my life? I have dwelt hitherto in joyous, loving wedlock; whither shall I turn now? To the secular calling, or into holy orders? Both stand open to me now. In my mind I have examined the lives of sundry men, assayed their worth and weighed them well: Imperfect, frail and tainted with sin have I found them all. Doubt besetteth me now as to whither I shall turn, for laden with frailty the being of all men seemeth to be. Sir Death, give advice; I stand in need of counsel.

In my heart of hearts I find, I think and believe it firmly, that such a pure and most-excelling house companion shall ever be found again. Upon my soul I declare that if I knew that another marriage like my former should fall to my lot, I would live in it as long as life coursed within me. For happy, gay, cheerful and full of mirth is a man possessed of a doughty wife wherever he may abide. For to such a man it is a joy to strive for vittals and vie for honor. For him it is also a joy to reward respect with respect, faith with faith, and blessing with blessing. $\mathrm{He}$ need not watch over his wife, for the best watch is that which 
a stout-hearted wife imposeth on herself. He, however, who will not have faith in his wife and trust her, must ever be beset by care.

Lord of the Heavens above, Prince of all bliss, happy he to whom Thou hast given such a pure bed-companion. Let him look up to Heaven and thank Thee with raisèd hands every day of his life. Do Thy best now, Sir Death, most capable Lord!

\section{8. 盈eath}

To praise without end, to revile without purpose, men are accustomed to do in whatever they undertake. But with praising and reviling there should be measure and fitness so that one knoweth how properly to use them when the need ariseth.

Thou praisest wedlock with main and might. Nevertheless shall We tell thee this about wedded life-without offence to virtuous women-: As soon as a man taketh unto himself a wife, the two of them are in Our prison. At once he hath an obligation, an appendage, a drag-sled, a yoke, a halter, a burden, a heavy load, a tormenting devil, a daily rasp, which, at law, he cannot be rid of unless We favor him with Our grace. A wedded man hath every day thunder showers, hailstorms, vixen and snakes in his house. A wife always aimeth to become master; if he draw up, she pulleth down; will he thiswise, she will thatwise; will he hither, she will thither-of this game he will have his fill and be without victory every day. Cheating and gain through cunning, flattering and fancying, caressing and back-talking, laughter and tears at the same moment, she understandeth well indeed; for these are innate to her. Too ill for work, well for lust, withal tame and wild is she as soon as she hath need of such. To find words for rebuttal she hath no need of lawyers. To do that which is forbidden, not do that which is bidden, she practiceth at all times. This is too sweet for her, that too sour; of this there is too much, of that not enough; now it's too early for her and now too late-in this manner everything is raked over. But if, after all, something is to be praised by her it hath to be warped shamelessly over a turner's lathe and withal life is ever admixed 
with derisive speech. There is no help for a man in wedlock: Be he too kind, or be he too stern, in each case he will be chastised with scath; let him be only half kind and half stern, there still is no way out. It always turneth into scolding and carping. Every day a new imposition, or-a scolding; every week outlandish demands, or-churlishness; every month vexatious filth, ordread; every year new clothes, or-daily rancor: these a wedded man must endure, no matter what he do. Of the vexations of the night We shall keep resolutely still, for at Our age We are ashamed of it.

Would We not spare the goodly women, We could sing thee many another song and tell many a tale about the useless ones. Therefore look well at what thou praisest; thou canst not tell gold from lead!

\section{The 坊laintitf}

Revilers of womanhood must be reviled in turn, sayeth the master of truth. How fare it with Thee now, Sir Death? Thy unreasoning slander of womanhood-even, though done with women's sufferance,--redoundeth to Thy disgrace and maketh good women blush.

In the writings of many a wise master one readeth that without woman's helmcraft no man can steer securely toward happiness. For the possession of wife and children is not the meanest part of earthly happiness. With this truth wise Mistress Philosophy brought peace of mind to Boëthius, the consoling Roman. Every thoughtful and wise man will bear me witness: No man's upbringing can stand the test, it be then tempered by women's ways. Say what Thou willt: A well-bred, beautiful and chaste wife, unblemished in all her virtues, surpasseth all earthly joys the eye can behold. Never have I seen a valiant man, who proved himself singularly unflinching, who was not lent wings by a woman's cheerful encouragement. One seeth it every day, wherever valorous men assemble: in all market places, at every court, in all tournaments, at every summons to arms, t'is always the women who bring about the best. He that hath espoused the 
service of women, must forgo all evil ways. Proper behavior and honorable respect are taught by sterling women in their schools. Over earthly joys, also, do women hold the reins for they bring it to pass that all well-mannered pastime be done in their honor. With the wag of a woman's finger the brave man is warned and chastised more surely than by any threat of arms.

In brief and without embellishment: Good women are the maintenance, the strengthening and increase of every man. Save and except that with gold there needs be lead; with wheat, weeds; with every minting of coin, refuse; with women, vixen. But let not the good ones bear the brunt for the wicked ones. Believe me that, Captain of Underhill!

\section{0. 焣eath}

A clod for a nugget of gold, a piece of horn for a topaze, a pebble for a ruby, the fool ever taketh; the hay-barn for a castle, the Danube for the ocean, the sparrow hawk for the peregrine, the fool always mistaketh. In like manner thou praisest the eye's rapture but seest not the root of things. For thou ignorest that everything in the world is either the desire of the flesh, the covetousness of the eyes, or the proud aspiring of life. Fleshly desire trendeth toward lust, covetousness of the eye toward possession and goods, proud aspiring toward honors. Possession bringeth avarice in its train, lust maketh wanton, honors bring boastfulness and pride in their train. From possession must ever issue vacillation and fear, from lust must come evil thought and sin, and from honors vanity. Couldst but recognize this, thou wouldst find but idle tattle in the whole world; should suffering or joy then come thy way, thou wouldst suffer both with grace and wouldst leave Us unreproved.

But for as much as the jackass comprehendeth the harpist's art, thou canst recognize the truth. For this reason We are so much troubled for thy sake. When We tore Pyramus, the youth, from Thisbe, the maiden, who both in heart and soul were one; when We wrested from King Alexander the dominion of the world, when we laid low the Trojan Paris and Greece's fair 
Helena, We were never so sorely berated as by thee. Nor did We suffer so much distress with the Emperor Charles, the margrave William, Theoderic of Verona, the rugged Boppe and the scaly Siegfried. Down to this day men bewail Aristotle and Avicenna and, yet, no one assaileth Us therefor. When David, the mighty king, and Solomon, the quintessence of wisdom, came to dying, more thanks than curses were Our share. They who once trod the earth have all passed on; thou, and all who now are and are yet to be born, must follow in their train. In defiance of everything, We, Death, here remain Lord!

\section{The 独laintiff}

His speech at times condemneth a man, especially one who speaketh now thiswise, now thatwise.

Thou hast said afore: Thou werest something and yet nothing. Thou werest no spirit but the end of life and that all men on earth were in Thy keeping. And now Thou sayest: We must all pass away and Thou, Sir Death, remainest here Lord! Two opposing words cannot together be true. If all of us must part from life, if all life on earth must come to an end and if Thou, as Thou sayest, art the end of life, so must I ask: If there be life no more, there needs be also no more dying and no death-Whither: goest Thou then, Sir Death? In Heaven Thou durst not dwell for it is apportioned to naught but gentle spirits; and, according to Thine earlier speech, Thou art no spirit. When then on earth Thou hast nothing further to perform and earth itself no longer existeth, then Thou needs must go straightway to Hell, to wail there without surcease. Then, too, the living and the dead will be avenged on Thee.

No one can steer his course by Thy contradictory speech. Should all things on earth have been created and shaped in manner so evil, pitiful and useless? Of that the Eternal Creator hath never been accused since Creation's Day. Down to the present, God hath ever loved virtue, despised evil thought, punished and forgiven sin. Methinks, He will continue doing so. From the days of my youth I have read and learned in books how God cre- 
ated all and sundry things. Thou statest that all being and life on earth shall have an end. Opposed to this, however, Plato and other philosophers say that, with all things, the destruction of one is but the birth of another and that all things are based on re-birth and that the events of Heaven and of Earth are naught but one eternal action, transmuting to the other from the one.

With Thy double-edged speech, on which no man can build, Thou wouldst afright me from my suit. Therefore, Sir Death, Thou vile Destroyer, I convoke myself with Thee before God, my Redeemer! May God adjudge to Thee an ill-favored Amen!

\section{2. 盈eath}

Oft, when a man hath begun to speak, he cannot stop again, unless he be interrupted. From such a die thou hast been cast.

We have said and say it again and, with it, wish to put an end: The Earth and all that is within it, is built on shifting sand. In these days, forsooth, it hath become most changeful, for all things are turned about: the backside is foremost, the forepart behind; the bottomside is up and the top at the bottom; perversion hath been turned into law by the great multitude of the people. We, however, have brought the whole of the human race into the constancy of the fire's flames. To find a good, true and helpful friend hath become, on earth, almost as possible as grasping a beam of light. All men are more disposed toward evil than to inborn virtue. And if someone doeth some good thing, he doth it out of fear of Us. Men in all their hustle are full of empty bustle. Their bodies, their wives and children, their honor, their possessions and all their powers fly away, in one short moment they disappear and are whirled away by the wind. Neither substance nor shadow can persist.

Pay heed, probe, see and perceive what the children of men possess now on earth: How they, for the sake of earthly possession, have fathomed hill and dale, stick and stone, alps and the wilderness, the bottom of the sea and the deeps of the earth; how they have dug shafts, galleries and yawning pits into the earth, burrowed in its veins for glittering ores which, because of their 
rarity, they prize above all other things; how they fell trees and, like the swallows, lime together walls, fences and houses; how they plant and prune orchards, till the soil, stake up vineyards, build mills, heap interest upon interest, carry on fishing, hunting and poaching, raise up large herds and flocks, keep scores of menservants and handmaidens, ride proud steeds, fill their houses and chests with gold, silver and precious stones, with beautiful raiments and all kinds of possessions, enjoy rapture and lust whereafter they trend and seek day and night-what is all this? All is vanity, injurious to the soul, transitory as the yesterday which has passed beyond recall. With war and venery they make their gain; for the more is possessed, the more is robbed. Then they leave it all as inheritance for renewed quarrels and dissension.

Alas, mortal mankind liveth evermore in fear, in misery and grief, in sorrow and care, in anxiety and shuddering, in days of woe and sickness, in mourning, affliction, wailing and sadness and in adversities of sundry kind. And the more a man is possessed of earthly goods, the more the adversities compound to which he is heir. And, withal, the heaviest burden is, that no man knoweth when, where and how, We shall pounce on him with one fell stroke and drive him along the way of all flesh. This burden must be borne by master and servant, man and wife rich and poor, good and bad, young and old. Oh, painful certain prospect, how little the fools pay it heed. When the sand hath run out, all would pious be. All this is vanity of vanities, and an encumbrance to the soul.

Therefore be done with thy wailing and enter into whatever estate thou wouldst, thou wilt find frailty and idle bustle in each. But turn thyself away from evil and do good; seek out the peace which surpasseth understanding and show it at all times; prize, however, above all things of earth, an undefiled clear conscience.

And that thou mayst know that We have counseled thee truly, We shall stand with thee before God, the Eternal, the Great, the Almighty. 


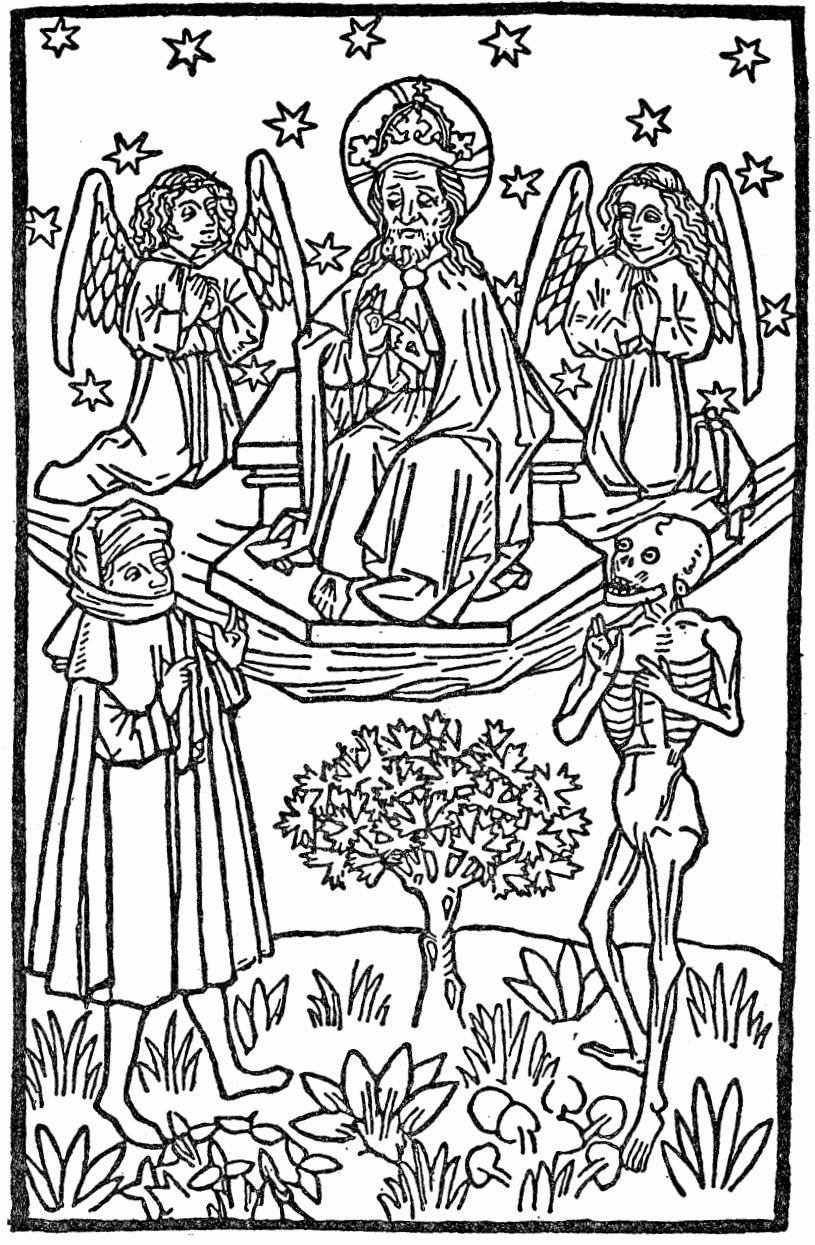




\section{The Jutumment of (16mi}

Spring, Summer, Fall and Winter, the four quickeners and helpers of the year, once fell out with each other in a great dispute. Each of them boasted of his good will in wind, rain, thunder, hail, snow and weather of every hue and each wanted to be the best according to his efficacy.

Spring said that he refreshed and made profuse all fruit; Summer claimed that he ripened and matured every fruit; Fall vaunted that he brought home, and carried for the other two, all fruit into barn, cellar and house; Winter boasted that he consumed and ate up all fruit and drove away injurious vermin. They puffed and quarrelled zealously but they had forgotten that, in bragging, they had laid claim to absolute dominion.

In like fashion are ye doing: The plaintiff mourneth his loss as though it were his rightful heritage; he giveth no thought that it was loaned to him by Us. Again, Death boasteth of warranted dominion which, forsooth, he holdeth but in fief from Us. The former lamenteth what belongeth not to him; the latter vaunteth a power which he possesseth not of himself. However, the quarrel is not without sense and ye both have fought well. Sorrow forced the former to bring suit, the latter is constrained by the plaintiff's charge to tell the truth.

Therefore, to thee, Plaintiff, be honor; to thee, Death, however, victory. Each man is bounden to give to Death his life, to Earth his body, his soul to Us.

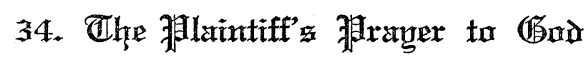

(I) Ever watchful Guardian of the World; God above all gods; Wonder-working Lord over all lords; Almighty Spirit above all spirits; Ruler above all sovereign majesty; Fount from which all goodness floweth; Sanctifier of all saints; Crown-Dispenser and the Crown itself; Paymaster and the Reward itself; Electoral Prince in whose hand lieth every king's anointing! Blessèd he who maintaineth his fealty to Thee! Joy and Delight of Angels; Expression of the Sublimest Forms; Greybeard and Youth in One, Hear my prayer! 
(O) Light which needeth no other light; Light which outshineth and dulleth every other light; Gleam before which aught other gleam doth fade; Glow compared with which all light is darkness; Incandescence before which aught casteth shadow; Light which at the beginning of the world spake: "Become light?" Unquenched Fire which burneth everlastingly; Alpha and Omega in one, Hear my prayer!

(H) Bliss and Blessedness beyond all bliss; Way without détour to Life Everlasting; Good without which there is no other good; Life from which all things draw life; Truth above all truth; Wisdom which encompasseth all wisdom; Gateway of all strength; Surveyor of every wrong-doing; Helper in all infirmities and faults; Satisfier of the needy; Comforter of the sick; Seal of the Most High Majesty; Keystone of celestial harmony; Sole Discerner of all human thought; Versatile Sculptor of all human countenance; Sovereign Planet of all planets; Sole Guiding Ruler of the firmament; Mighty, Glorious Master of the Heavenly Court; Law before which the celestial order can never leave its eternal fulcrum; Fair Sun, Hear my prayer!

(A) Helpful Physician in all illness; Master of all masters; Sole Father of all creation; on all paths, in every stead, Everpresent Overseer; Arbitrary Guider from mother's womb to earth's tomb; Fashioner of every form; Base Rock of all good works; Lover of all truth; Hater of all lewdness ; Recompenser of all good deeds; Sole Just Judge; Arbiter from whose dispositions not one thing may deviate in all eternity, Hear my prayer!

(N) Helper in need and all distress; Firm knot which no man can unravel; Perfect Being in whose hands resteth all perfection; Knower, forsooth, of all secret and hidden things; Dispenser of everlasting joy; Disburser of earthly rapture; Host, Servant and House Companion of all good men; Hunter to whom no trail remains hidden; Exquisite Mould of all sensation; Judge and Conciliator; Equator of all measures of the orbit; Gracious Auditioner of all who cry to Thee, Hear my prayer!

(N) Ever Ready Support of all in need; Comforter of all whose hope resteth in Thee; Satisfier of the hungry; All-Powerful 
Creator who from naught can create aught, from aught naught; Animator of every weal, of all beings, mortal and immortal; Preserver and Destroyer of life; Thou who hast thought out, shaped, designed and endowed with color all things, Hear my prayer!

(E) Everlasting Beacon; Eternal Light; True-Steering Helmsman whose ship doth never founder; Banner-Bearer under whose ensign no victory is in jeopardy; Originator of Hell; Architect of the round of Earth; Tamer of the foamy sea; Blender of the footless winds; Kindler of the fire's glow; Creator of the elements; Sole Governor of the thunder, lightning and fog, of hail, snow and rain, of the rainbow and the mildew, the wind and the frost and all their actions; Mighty Duke of the Heavenly Legions; Emperor to whom none can deny service; Most Gentle, Most Powerful, Most Merciful Creator, Have mercy upon me and Hear my prayer!

(S) Treasure from which all treasures spring; Fountain Head from which all clear waters course; Guide with whom none stray off the path; Helper in need toward Whom all things do press as bees seeking their queen; Cause of all causes, Hear my prayer! (G) Good beyond all possessions, Most Worthy Lord Jesus, graciously receive into Thy hands the soul of my dearly belovèd wife, grant her eternal rest, lave her with the dew of Thy grace, keep her in the shadow of Thy wings, take her, oh Lord, into Thy perfect peace, wherein the least and the foremost find fullest satisfaction. Give leave to her, oh Lord, to return to Thy kingdom, whence she had come, and dwell there with the blessed eternal spirits!

(M) I grieve for Margaret, my chosen wife. Grant her, Most Gracious Lord, eternally to see, contemplate and rejoice herself in the mirror of Thy divinity whence all angels derive their light! (A) To all sundry, to whatsoever is created and belongeth under the banner of the Eternal Banner-Bearer, I call for help to speak with me, from the inmost heart, in blessedness and blissfulness, a deep "Amen!" 


\section{Appendix.}

Key: $-B$. Bernt's notes

-T. Translator's notes

Chapt. 1. The known MSS are classified into the lant, 'land', group and the leut, 'people', group according to which variant appears as the fourth word of the opening chapter. The three known Czech MSS together with MS. E constitute the former group; all others, together with the printed copies (1462-1547), the latter. $-T$.

Chapt. 3. The plaintiff identifies himself as a man who uses the pen (quill) in the exercise of his profession. The twelfth letter of the alphabet (before the adoption of the letter J. -T.) is M. His wife's name is Margaret, as can be seen from the conclusion of the last chapter. $-\boldsymbol{B}$.

Chapt. 4. The letters give the name Sacz, as Saaz (Cz. Zatce) was spelled in old documents. The city lies on a ridge overlooking the middle course of the Eger river and still shows remnants of the old city fortifications. $-B$.

Chapt. 5. Bernt writes glänzender Morgenstern, 'brilliant morning star', for fluetender morgenstern. Cf. the discussion of the Mystics' das fliessende Licht der Gottheit, "the flooding light of the Godhead", in R. Sommerfeld-Brand, "Zur Interpretation des AaB" Monatshefte, XXXII (Dec. 1940), 387-397. $-T$.

Chapt. 14. The wife died on August 2, 1400 (St. Peter's Chain Feast). $-B$. Some calendars list this holiday for August first. The year 1400 was the Church's second jubilee year, i.e., a year of remission during which plenary indulgence could be obtained by a pilgrimage to Rome, or other pious works. Bernt also writes kurze Elend, 'short misery', for kurz scheinende ellende, 'short seeming misery'; scheinen, 'seem', in earlier German meant 'shine' (the English 'appear' has undergone a similar shift to 'seem'). Cf. Hans Sperber, "Im Spiegel der Sprache: IV. Eindruck," Monatshefte, XXXII (April 1940), 178182, where he credits the $A a B$ as a source for the Pietists' glänzendes Elend, 'glittering misery'. $-T$.

Chapt. 16. All the MSS of the leut-group have the phrase *wanderend an allen enden der werlt (Hammerich-Jungbluth), 'wandering at all the ends of the world', as a modifier of the "basilisk-eyed man" toward the end of the fourth paragraph. MS. E unfortunately breaks off in the fourteenth chapter. $T k$, the remaining lant-group representative does not use the phrase at that spot but gives its substance in a lengthy paraphrase at the opening of that paragraph: "For We are from everywhere, although We are from nowhere. From everywhere are We thiswise: There be no place, nor nook, in any land on the 
whole earth without Our having been there, without Our having sojourned there by virtue of Our power and Our dominion. . . .And from nowhere are We thuswise: That We are come from nowhere and from naught." $-T$.

Chapt. 18. Death enumerates events from history and legend in which ambitious men had shown sagacity, adroitness and courage. All these people resemble the plaintiff who, in the eyes of Death, is simply Man whose striving, in Death's opinion, was ever idle.- $B$.

Chapt. 20. The philosopher is Seneca who, as representative of the Stoic school, was read much in the Middle Ages; he is also the one who, in Chapt. 18, has been referred to as Nero's teacher. During the Middle Ages numerous religio-philosophical writings were attributed to the philosopher Hermes. $-B$.

Chapt. 24. The frailty of the human body was a favorite theme of ecclesiastic-ascetic writing. $-B$.

Chapt. 26. Knowledge of the Trivium and the Quadrivium, as well as of the secret arts compared to them here, is of no avail before Death. $-B$.

Chapt. 29. The plaintiff calls Death Hauptmann vom Berge (lit. 'captain of the mountain', fig. 'mine foreman' $-T$.) in contradistinction to God whom he calls "Lord of the Heavens above" in Chapt. 27. $-B$. Recent research, however, indicates that this interpretation of the epithet may, at best, be only a secondary meaning in an intentional play on words. A brief footnote made by Wackernagel a century ago, and until recently ignored because insufficiently understood, equated the term with the "Old Man of the Mountain". Wolfgang Fleischhauer in his well-documented article "The 'Ackermann aus Böhmen' and the Old Man of the Mountain" (Monatshefte, XLV, April-May 1953, 189-201) shows that this is the popular name by which the dreaded Vetus de Monte, Rex Mortis, the absolute Head of the secret Ismaili Order of the Assassins was then known. The appellation Hauptmann, 'captain', as such, does not occur in any of the examples cited. That medieval Europe had been properly impressed by the activities of this early "Murder, Inc." is proven by the almost universal adoption of the word 'assassin' into its languages and by the many references to the sect and its leader in historical documents, troubadour songs and legendary tales such as Marco Polo's spicy account of his supposed visit to the Old Man and his "Paradise." Real and imagined assassination attempts against various crowned heads played important roles in the power politics of the day. Thus Richard the' Lionhearted's imprisonment in Germany upon his return from the Holy Land was, at least in part, due to the accusation that he had hired the Assassins who murdered Conrad of Montferrat, the newly elected King of Jerusalem, and threatened the life of Philip Augustus of France. 
Pope Innocent IV laid a similar charge against Frederic II in 1245 when he excommunicated and dethroned the German Emperor. $-T$.

Chapt. 30. Pyramus and Thisbe were, like Paris and Helena, one of the better known pairs of lovers during the Middle Ages. $-B$.

Chapt. 31. Plato's teaching of the endless round of life and rebirth occurs in the dialogue Phaedon and was echoed in many writings of Antiquity. $-B$.

Chapt. 34. The (German) initials of the paragraphs form an acrostic of the author's name: Iohannes. $-B$. There can be no doubt about the first five paragraphs giving the acrostic $I O H A N$; there is justifiable doubt, though, as to the rest. If we take account of the fine style consciousness of the author of the $A a B$, the suspicion arises that a transposition of the closing pages of the MS was not detected by an early copyist. Jarring are the uneven lengths of the litany-style paragraphs, as well as the anti-climactic resumption of previous phrase patterns after the crescendo of the adoration synonyma has been reached in "Duke-Emperor-Creator." Krogmann, in "Das Akrostichon im Ackermann," Festschrift für Wolfgang Stammler, (Berlin 1953), offers a temporarily satisfying rearrangement of lines resulting in the acrostic IOHANNES M[agister] A[rtium]. $-T$. 

